\title{
Implementation of Single Moving Average Methods For Sales Forecasting Of Bag In Convection Tas Loram Kulon
}

\author{
Evita Noor Sofiana Dewi ${ }^{1}$, Ahmad Abdul Chamid ${ }^{2}$ \\ ${ }^{1}$ Program Studi Teknik Informatika, Fakultas Teknik, Universitas Muria Kudus \\ Jl. Gondangmanis Bae Kudus Jawa Tengah, e-mail: 201551005@std.umk.ac.id \\ 2 Program Studi Teknik Informatika, Fakultas Teknik, Universitas Muria Kudus \\ Jl. Gondangmanis Bae Kudus Jawa Tengah, e-mail: abdul.chamid@umk.ac.id
}

ARTICLE INFO

Article history:

Received 15 November 2018

Received in revised form 20 December 2018

Accepted 25 January 2019

Available online 25 January 2019

\begin{abstract}
Convection Tas Loram Kulon is a Small and Medium Enterprises (UKM) located in the village of Loram Kulon, Jati Sub District, Kudus Regency. The amount of effort makes everyone compete to be the best to get customers. When business owners cannot use information technology, a lot of information is wasted. Forms of manual reporting make it difficult for the owner to see the development of the business, as a result the owner can make mistakes in making decisions, especially for the addition or reduction of the stock. Forecasting is an estimate of the level of demand for one or more products over the coming periods. In forecasting the estimated level of demand in order to avoid excesses and not less inventory quantities based on past sales. Decision support investigated to predict the number of sales using the single moving average method. The Single Moving Average method uses a number of actual data requests to generate forecast values. The calculation is done by taking a group of values or data and then calculating the average and with the average used to calculate the next period forecast. from the results of the prediction or calculation, bag sales can be used to make policies in the production of bags, so that the owner gets information for the production of bags in the following month, or in certain months according to the results of predictions bag sales.
\end{abstract}

Keywords: Decision support, single moving average, forecasting

\section{Pendahuluan}

Konveksi Tas Loram Kulon merupakan Usaha Kecil Menengah (UKM) yang berada pada desa Loram Kulon Rt 2 Rw 1 Kecamatan Jati Kabupaten Kudus. Salah satu aspek strategis perusahaan agar dapat bersaing dalam dunia bisnis adalah perencanaan dan tersedianya produk untuk memenuhi tuntutan pasar. sehingga kemampuan dalam meramalkan keadaan bisnis dimasa depan sangat dibutuhkan. Permasalahan yang dihadapi oleh pemilik konveksi adalah bagaimana Received November 15, 2018; Revised December 20, 2018; Accepted January 25, 2019 
meramalkan penjualan produk di masa mendatang berdasarkan data yang telah direkam sebelumnya. Peramalan tersebut sangat berpengaruh pada keputusan pemilik untuk menentukan jumlah produksi tas yang harus disediakan oleh konveksi. Beberapa permasalahan yang sering ditemukan dalam pengelolaan ketersediaan produk yaitu kurangnya ketersediaan jumlah stok produk atau juga jumlah stok produk yang berlebih. Kurangnya ketersediaan jumlah stok produk berakibat pada tidak terpenuhinya permintaan dari customer, sedangkan kelebihan jumlah stok produk berakibat pada kerugian konveksi karena konveksi terlalu lama menyimpan modal atau produk.

Untuk mengatasi permasalahan tersebut pihak konveksi harus dapat merencanakan jumlah stok produk yang akan disimpan, sehingga tidak terjadi kelebihan stok produk maupun terjadi kekurangan stok produk yang akan menghambat pekerjaan. Salah satu solusi untuk mengatasi permasalahan tersebut yaitu dengan memprediksi atau meramalkan penjualan atau permintaan produk oleh customer dengan menggunakan metode ilmiah peramalan yang diterapkan kedalam suatu aplikasi berbasis komputer. Berbagai metode telah diterapkan dalam melakukan peramalan, dan berbagai studi kasus telah diteliti salah satunya peramalan jumlah korban demam berdarah [1].

Metode peramalan adalah sebuah metode yang mampu melakukan analisa terhadap sebuah faktor atau beberapa faktor yang diketahui mempengaruhi terjadinya sebuah peristiwa dengan terdapat waktu tenggang yang panjang antara kebutuhan akan pengetahuan terjadinya sebuah peristiwa di waktu mendatang dengan waktu telah terjadinya peristiwa tersebut dimasa lalu [2]. Forecasting (peramalan) merupakan alat bantu yang penting dalam perencanaan yang efektif dan efisien khususnya dalam bidang ekonomi. Peramalan merupakan bagian dalam sistem pendukung keputusan yang dapat membantu pengambil keputusan, berbagai metode telah diterapkan dalam sistem pendukung keputusan [3]. Dalam organisasi modern mengetahui keadaan yang akan datang tidak saja penting untuk melihat yang baik atau buruk tetapi juga bertujuan untuk melakukan persiapan forecasting. Beberapa metode peramalan seperti single moving average sering digunakan pendukung keputusan dalam peramalan terhadap data-data historis. Sistem pendukung keputusan mampu memberikan masukan bagi pengambil keputusan secara objektif [4].

Kelebihan dari metode Single Moving Average dapat digunakan sebagai peramalan untuk menghitung rata-rata hasil penjualan tas pada periode tertentu yang akan terus dihitung berdasarkan pergerakan data, metode ini sangat efektif, mudah dan lebih efisien proses perhitungannya, karena sistem perhitungannya tidak memerlukan pembobotan pada setiap data.

Berdasarkan permasalahan tersebut maka perlu dibangun sebuah sistem untuk meramalkan penjualan tas khususnya pada Konveksi Loram Kulon dengan tujuan memberikan gambaran terhadap penjualan tas pada bulan selanjutnya.

\section{Metode Penelitian}

\section{A. Single Moving Average}

Metode single moving average atau juga disingkat SMA adalah salah satu metode dari moving average yang paling efisien dalam proses perhitungannya, Single Moving Average merupakan metode peramalan yang dilakukan dengan mengambil sekelompok nilai pengamatan, kemudian mencari rata-ratanya sebagai ramalan untuk periode mendatang [5].

Metode Single Moving Average tidak menggunakan pembobotan pada setiap data yang akan dihitung. Meskipun sederhana dan sangat efisien, SMA cukup efektif dalam menentukan trend yang sedang terjadi dimarket. Metode Single Moving Average memiliki ciri khusus [6] yaitu :

1. Diperlukan data historis selama periode tertentu untuk menentukan ramalan.

2. Semakin panjang jangka waktu moving average, efek pelicinan semakin terlihat dan hasil moving average nya semakin halus.

TRANSFORMATIKA Vol.16, No.2, January 2019, pp. 113 - 125 
Persamaan matematis Single Moving Average dapat dituliskan sebagai berikut [7]:

$$
\mathrm{Mt}=\mathrm{Ft}+1=(\mathrm{Yt}+\mathrm{Yt}-1+\mathrm{Yt}-2+\cdots+\mathrm{Yt}-\mathrm{n}+1) / \mathrm{n}
$$

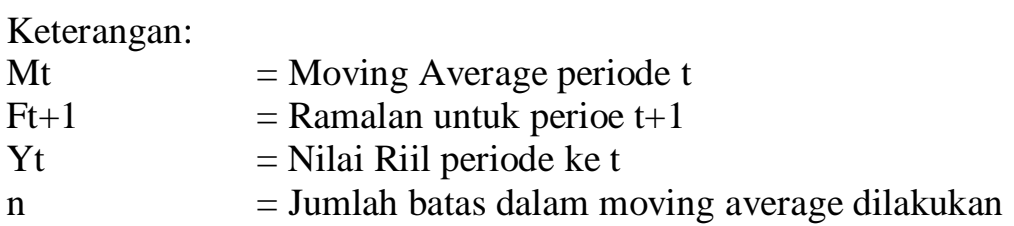

B. Pengujian

MSE merupakan salah satu metode pengujian kesalahan yang sering digunakan untuk mengukur tingkat akurasi hasil peramalan suatu model [8]. Cara menghitung MSE adalah dengan mencari rata-rata dari jumlah kuadrat kesalahan. MSE juga dapat menyatakan ukuran besarnya kesalahan yang dihasilkan oleh suatu model prakiraan. Semakin rendah nilai MSE maka semakin kecil pula kesalahan dalam peramalan dan hasilnya semakin mendekati variasi nilai observasinya.

Persamaan matematis MSE dapat dituliskan sebagai berikut [9] :

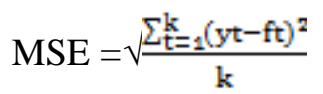

Keterangan :

$\mathrm{k}=$ Jumlah sample data

$\mathrm{ft}=$ Nilai prediksi ke- $\mathrm{t}$

$\mathrm{yt}=$ Nilai data ke- $\mathrm{t}$

\section{Hasil dan Analisa}

Dalam bagian ini akan disimulasikan perhitungan single moving average untuk forecasting penjulan tas.

\subsection{Data Yang Digunakan}

Data yang digunakan pada penelitian ini adalah data penjualan tas pada konveksi tas loram kulon tahun 2013 sampai dengan tahun 2017.

Tabel 3.1 : Data Penjualan Tas Pada Konveksi Tas Loram Kulon

\begin{tabular}{llll}
\hline Tahun & Bulan & Penjulan (ds) & $\begin{array}{l}\text { Penjulan } \\
(\mathrm{pcs})\end{array}$ \\
\hline \multirow{6}{*}{2013} & Januari & 110 & 1320 \\
& Februari & 100 & 1200 \\
& Maret & 135 & 1620 \\
& April & 130 & 1560 \\
& Mei & 175 & 2100 \\
& Juni & 160 & 1920 \\
& Juli & 190 & 2280 \\
& Agustus & 260 & 3120
\end{tabular}

Implementation of Single Moving Average Methods For Sales Forecasting Of Bag In Convection Tas Loram Kulon (Dewi) 


\begin{tabular}{|c|c|c|c|}
\hline & September & 220 & 2640 \\
\hline & Oktober & 185 & 2220 \\
\hline & November & 200 & 2400 \\
\hline & Desember & 220 & 2640 \\
\hline & Januari & 285 & 3420 \\
\hline & Februari & 280 & 3360 \\
\hline & Maret & 285 & 3420 \\
\hline & April & 255 & 3060 \\
\hline & Mei & 270 & 3240 \\
\hline 2014 & Juni & 235 & 2820 \\
\hline 2014 & Juli & 250 & 3000 \\
\hline & Agustus & 270 & 3240 \\
\hline & September & 285 & 3420 \\
\hline & Oktober & 280 & 3360 \\
\hline & November & 285 & 3420 \\
\hline & Desember & 270 & 3240 \\
\hline & Januari & 275 & 3300 \\
\hline & Februari & 295 & 3540 \\
\hline & Maret & 285 & 3420 \\
\hline & April & 290 & 3480 \\
\hline & Mei & 300 & 3600 \\
\hline 2015 & Juni & 295 & 3540 \\
\hline 2015 & Juli & 295 & 3540 \\
\hline & Agustus & 285 & 3420 \\
\hline & September & 265 & 3180 \\
\hline & Oktober & 250 & 3000 \\
\hline & November & 235 & 2820 \\
\hline & Desember & 250 & 3000 \\
\hline & Januari & 245 & 2940 \\
\hline & Februari & 220 & 2640 \\
\hline & Maret & 180 & 2160 \\
\hline & April & 185 & 2220 \\
\hline & Mei & 210 & 2520 \\
\hline 2016 & Juni & 245 & 2940 \\
\hline & Juli & 260 & 3120 \\
\hline & Agustus & 285 & 3420 \\
\hline & September & 290 & 3480 \\
\hline & Oktober & 275 & 3300 \\
\hline & November & 285 & 3420 \\
\hline & Desember & 300 & 3600 \\
\hline 2017 & Januari & 300 & 3600 \\
\hline
\end{tabular}

TRANSFORMATIKA Vol.16, No.2, January 2019, pp. 113 - 125 


\begin{tabular}{lll} 
Februari & 275 & 3300 \\
Maret & 290 & 3480 \\
April & 315 & 3780 \\
Mei & 295 & 3540 \\
Juni & 300 & 3600 \\
Juli & 275 & 3300 \\
Agustus & 300 & 3600 \\
September & 310 & 3720 \\
Oktober & 185 & 2220 \\
November & 190 & 2280 \\
Desember & 160 & 1920 \\
\hline
\end{tabular}

\subsection{Perhitungan Single Moving Average}

Pada perhitungan single moving average pada data penjualan tas menggunakan 3 periode moving average yang berbeda. Untuk menentukan ramalan pada periode yang akan datang memerlukan data historis sebagai parameter selama jangka waktu tertentu. Parameter yang digunakan yaitu $\mathrm{Ma}(3), \mathrm{Ma}(5)$, dan $\mathrm{Ma}(7)$.

\subsubsection{Perhitungan Single Moving Average Menggunakan Ma(3)}

Pada perhitungan single moving average pada penjualan tas menggunakan $\mathrm{Ma}(3)$ menghasilkan ramalan penjualan sebesar 2140 pcs. Pengujian MSE yang dilakukan menghasilkan 57 data dengan nilai MSE 174779. Hasil perhitungan tersebut diambil dengan cara $\mathrm{Ma}(3)$ atau data diambil dari hasil data penjualan 3 bulan sebelumnya (januari, februari, maret) untuk mendapatkan nilai rata-rata bulan april. Data penjualan dari waktu 3 bulan tersebut kita rataratakan dan mendapat hasil 1380, lakukan proses yang sama pada bulan berikutnya (februari, maret, april) untuk mendapatkan nilai rata-rata bulan mei dan bulan selanjutnya. Kemudian kita jumlahkan data nilai rata-rata tersebut, mulai dari awal pertama menghitung nilai rata-rata, dan mendapatkan hasil 57 data. Proses perhitungan selanjutnya yaitu mengukur tingkat akurasi pada setiap data, dengan memasukkan rumus MSE untuk menentukan nilai eror. Dari data Ma(3), hasil penjualan pada bulan april dikurang dengan hasil $\mathrm{Ma}(3)$ kemudian dikuadratkan, dan mendapat nilai eror 32400. Lakukan proses yang sama pada setiap bulan berikutnya. Kemudian kita jumlahkan semua hasil nilai eror yang dikuadratkan sebelumnya. Dan mendapat nilai SSE 9962400, hasil tersebut dibagi dengan jumlah data yang dihitung. 996200/57 dan mendapatkan nilai MSE 174779.

Hasil perhitungan single moving average menggunakan $\mathrm{Ma}(3)$ dapat dilihat pada tabel 3.2.

Tabel 3.2 : Perhitungan Single Moving Average Menggunakan Ma(3)

\begin{tabular}{llllll}
\hline Tahun & Bulan & Penjulan (ds) & Penjulan (pcs) & Ma (3) & $\mathrm{e}^{\wedge} 2$ \\
\hline \multirow{4}{*}{2013} & Januari & 110 & 1320 & & \\
& Februari & 100 & 1200 & & \\
& Maret & 135 & 1620 & & \\
& April & 130 & 1560 & 1380 & 32400
\end{tabular}

Implementation of Single Moving Average Methods For Sales Forecasting Of Bag In Convection Tas Loram Kulon (Dewi) 


$\begin{array}{lllll}\text { Mei } & 175 & 2100 & 1460 & 409600 \\ \text { Juni } & 160 & 1920 & 1760 & 25600 \\ \text { Juli } & 190 & 2280 & 1860 & 176400 \\ \text { Agustus } & 260 & 3120 & 2100 & 1040400 \\ \text { September } & 220 & 2640 & 2440 & 40000 \\ \text { Oktober } & 185 & 2220 & 2680 & 211600 \\ \text { November } & 200 & 2400 & 2660 & 67600 \\ \text { Desember } & 220 & 2640 & 2420 & 48400 \\ \text { Januari } & 285 & 3420 & 2420 & 1000000 \\ \text { Februari } & 280 & 3360 & 2820 & 291600 \\ \text { Maret } & 285 & 3420 & 3140 & 78400 \\ \text { April } & 255 & 3060 & 3400 & 115600 \\ \text { Mei } & 270 & 3240 & 3280 & 1600 \\ \text { Juni } & 235 & 2820 & 3240 & 176400 \\ \text { Juli } & 250 & 3000 & 3040 & 1600 \\ \text { Agustus } & 270 & 3240 & 3020 & 48400 \\ \text { September } & 285 & 3420 & 3020 & 160000 \\ \text { Oktober } & 280 & 3360 & 3220 & 19600 \\ \text { November } & 285 & 3420 & 3340 & 6400 \\ \text { Desember } & 270 & 3240 & 3400 & 25600 \\ \text { Januari } & 275 & 3300 & 3340 & 1600 \\ \text { Februari } & 295 & 3540 & 3320 & 48400 \\ \text { Maret } & 285 & 3420 & 3360 & 3600 \\ \text { April } & 290 & 3480 & 3420 & 3600 \\ \text { Mei } & 300 & 3600 & 3480 & 14400 \\ \text { Juni } & 295 & 3540 & 3500 & 1600 \\ \text { Juli } & 295 & 3540 & 3540 & 0 \\ \text { Juni } & 245 & 3420 & 3560 & 19600 \\ \text { Juli } & 260 & 3180 & 3500 & 102400 \\ \text { Agustus } & 285 & 3000 & 3380 & 144400 \\ \text { September } & 290 & 2820 & 3200 & 144400 \\ \text { September } & 265 & 3000 & 3000 & 0 \\ \text { Oktober } & 250 & 2940 & 2940 & 0 \\ \text { November } & 235 & 2640 & 2920 & 78400 \\ \text { Desember } & 250 & 2160 & 2860 & 490000 \\ \text { Januari } & 245 & 2220 & 2580 & 129600 \\ \text { Februari } & 220 & 180 & 2340 & 32400 \\ \text { Maret } & 185 & 2300 & 409600 \\ \text { April } & 210 & 3160 & 102400\end{array}$

TRANSFORMATIKA Vol.16, No.2, January 2019, pp. 113 - 125 


$\begin{array}{llllll} & \text { Oktober } & 275 & 3300 & 3340 & 1600 \\ & \text { November } & 285 & 3420 & 3400 & 400 \\ & \text { Desember } & 300 & 3600 & 3400 & 40000 \\ & \text { Januari } & 300 & 3600 & 3440 & 25600 \\ & \text { Februari } & 275 & 3300 & 3540 & 57600 \\ & \text { Maret } & 290 & 3480 & 3500 & 400 \\ & \text { April } & 315 & 3780 & 3460 & 102400 \\ & \text { Mei } & 295 & 3540 & 3520 & 400 \\ 2017 & \text { Juni } & 300 & 3600 & 3600 & 0 \\ & \text { Juli } & 275 & 3300 & 3640 & 115600 \\ & \text { Agustus } & 300 & 3600 & 3480 & 14400 \\ & \text { September } & 310 & 3720 & 3500 & 48400 \\ & \text { Oktober } & 185 & 2220 & 3540 & 1742400 \\ \\ \text { November } & 190 & 2280 & 3180 & 810000 & \\ & \text { Desember } & 160 & 1920 & 2740 & 672400 \\ \\ \text { Januari } & & & 2140 & \text { SSE } \\ \end{array}$

\subsubsection{Perhitungan Single Moving Average Menggunakan Ma(5)}

Pada perhitungan single moving average pada penjulan tas menggunakan $\mathrm{Ma}(5)$ menghasilkan ramalan penjualan sebesar 2748 pcs. Pengujian MSE yang dilakukan menghasilkan 55 dengan nilai MSE 217657. Hasil perhitungan tersebut diambil dengan cara menggunakan data $\mathrm{Ma}(5)$ atau data diambil dari hasil data penjualan 5 bulan sebelumnya (januari, februari, maret, april, mei) untuk mendapatkan nilai rata-rata bulan juni. Data penjualan dari waktu 5 bulan tersebut kita rata-ratakan dan mendapat hasil 1560, lakukan proses yang sama pada bulan berikutnya (februari, maret, april, mei, juni) untuk mendapatkan nilai rata-rata bulan juli dan bulan selanjutnya. Kemudian kita jumlahkan data nilai rata-rata tersebut, mulai dari awal pertama menghitung nilai rata-rata, dan mendapatkan hasil 55 data. Proses perhitungan selanjutnya yaitu mengukur tingkat akurasi pada setiap data, dengan memasukkan rumus MSE untuk menentukan nilai eror. Dari data $\mathrm{Ma}(5)$, hasil penjualan pada bulan juni dikurang dengan hasil $\mathrm{Ma}(5)$ kemudian dikuadratkan, dan mendapat nilai eror 129600. Lakukan proses yang sama pada setiap bulan berikutnya. Kemudian kita jumlahkan semua hasil nilai eror yang dikuadratkan sebelumnya. Dan mendapat nilai SSE 11971152, hasil tersebut dibagi dengan jumlah awal data yang dihitung. 11971152/55 dan mendapatkan nilai MSE 217657.

Hasil perhitungan single moving average menggunakan $\mathrm{Ma}(3)$ dapat dilihat pada tabel 3.3.

Tabel 3.3 : Perhitungan Single Moving Average Menggunakan Ma(5)

\begin{tabular}{llllll}
\hline Tahun & Bulan & Penjulan (ds) & Penjulan (pcs) & Ma (5) & $\mathrm{e}^{\wedge} 2$ \\
\hline \multirow{4}{*}{2013} & Januari & 110 & 1320 & \\
& Februari & 100 & 1200 & \\
& Maret & 135 & 1620 & \\
& April & 130 & 1560 &
\end{tabular}

Implementation of Single Moving Average Methods For Sales Forecasting Of Bag In Convection 


\begin{tabular}{|c|c|c|c|c|c|}
\hline & Mei & 175 & 2100 & & \\
\hline & Juni & 160 & 1920 & 1560 & 129600 \\
\hline & Juli & 190 & 2280 & 1680 & 360000 \\
\hline & Agustus & 260 & 3120 & 1896 & 1498176 \\
\hline & September & 220 & 2640 & 2196 & 197136 \\
\hline & Oktober & 185 & 2220 & 2412 & 36864 \\
\hline & November & 200 & 2400 & 2436 & 1296 \\
\hline & Desember & 220 & 2640 & 2532 & 11664 \\
\hline & Januari & 285 & 3420 & 2604 & 665856 \\
\hline & Februari & 280 & 3360 & 2664 & 484416 \\
\hline & Maret & 285 & 3420 & 2808 & 374544 \\
\hline & April & 255 & 3060 & 3048 & 144 \\
\hline & Mei & 270 & 3240 & 3180 & 3600 \\
\hline 2014 & Juni & 235 & 2820 & 3300 & 230400 \\
\hline 2014 & Juli & 250 & 3000 & 3180 & 32400 \\
\hline & Agustus & 270 & 3240 & 3108 & 17424 \\
\hline & September & 285 & 3420 & 3072 & 121104 \\
\hline & Oktober & 280 & 3360 & 3144 & 46656 \\
\hline & November & 285 & 3420 & 3168 & 63504 \\
\hline & Desember & 270 & 3240 & 3288 & 2304 \\
\hline & Januari & 275 & 3300 & 3336 & 1296 \\
\hline & Februari & 295 & 3540 & 3348 & 36864 \\
\hline & Maret & 285 & 3420 & 3372 & 2304 \\
\hline & April & 290 & 3480 & 3384 & 9216 \\
\hline & Mei & 300 & 3600 & 3396 & 41616 \\
\hline 2015 & Juni & 295 & 3540 & 3468 & 5184 \\
\hline 2015 & Juli & 295 & 3540 & 3516 & 576 \\
\hline & Agustus & 285 & 3420 & 3516 & 9216 \\
\hline & September & 265 & 3180 & 3516 & 112896 \\
\hline & Oktober & 250 & 3000 & 3456 & 207936 \\
\hline & November & 235 & 2820 & 3336 & 266256 \\
\hline & Desember & 250 & 3000 & 3192 & 36864 \\
\hline & Januari & 245 & 2940 & 3084 & 20736 \\
\hline & Februari & 220 & 2640 & 2988 & 121104 \\
\hline & Maret & 180 & 2160 & 2880 & 518400 \\
\hline & April & 185 & 2220 & 2712 & 242064 \\
\hline 2016 & Mei & 210 & 2520 & 2592 & 5184 \\
\hline & Juni & 245 & 2940 & 2496 & 197136 \\
\hline & Juli & 260 & 3120 & 2496 & 389376 \\
\hline & Agustus & 285 & 3420 & 2592 & 685584 \\
\hline & September & 290 & 3480 & 2844 & 404496 \\
\hline
\end{tabular}

TRANSFORMATIKA Vol.16, No.2, January 2019, pp. 113 - 125 


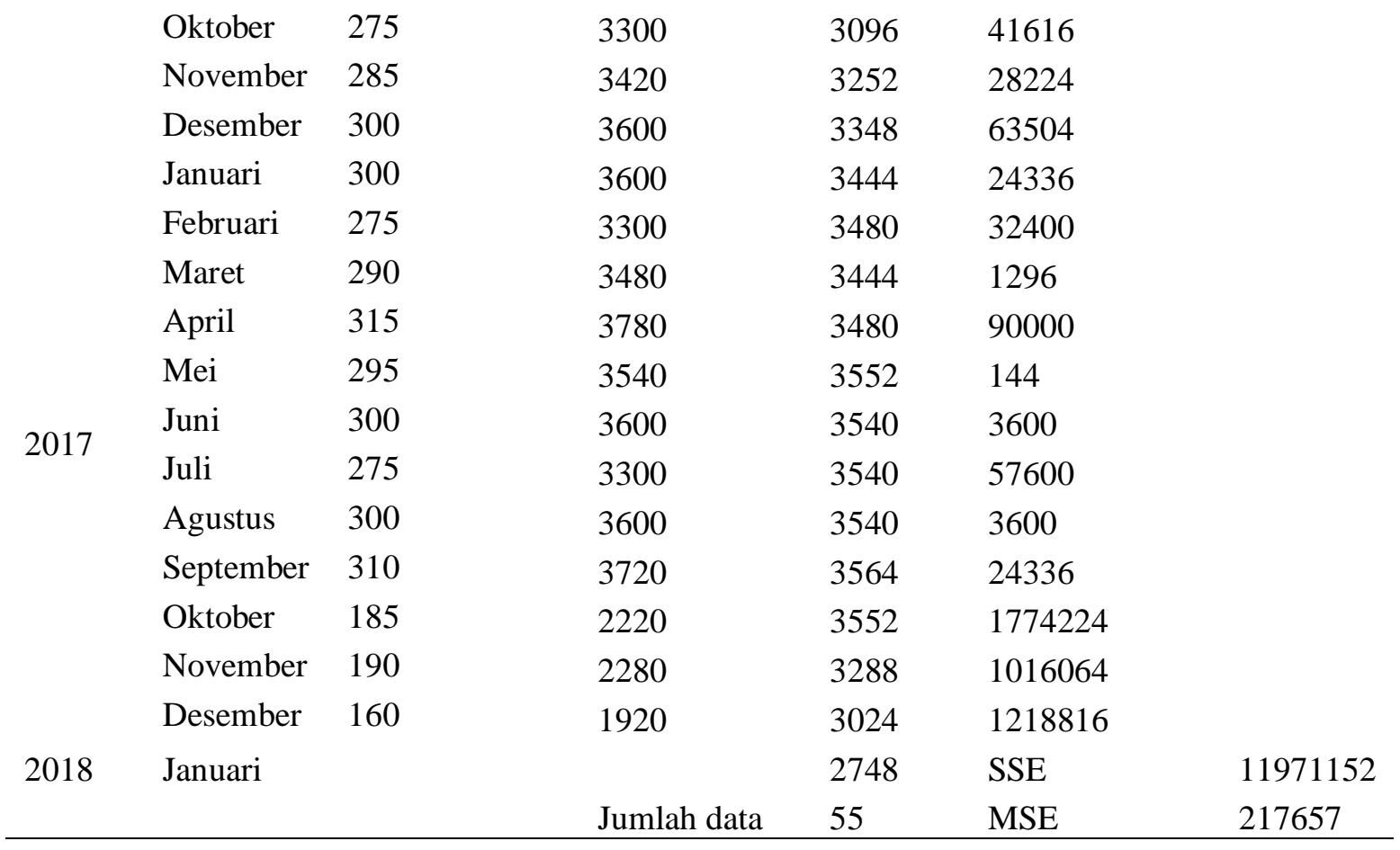

\subsubsection{Perhitungan Single Moving Average Menggunakan Ma(7)}

Pada perhitungan single moving average pada penjulan tas menggunakan $\mathrm{Ma}(7)$ menghasilkan ramalan penjualan sebesar 2948,571 pcs. Pengujian MSE yang dilakukan menghasilkan 53 dengan nilai MSE 264330. Hasil perhitungan tersebut diambil dengan cara menggunakan data $\mathrm{Ma}(7)$ atau data diambil dari hasil data penjualan 7 bulan sebelumnya (januari, februari, maret, april, mei, juni, juli) untuk mendapatkan nilai rata-rata bulan agustus. Data penjualan dari waktu 7 bulan tersebut kita rata-ratakan dan mendapat hasil 1714,296, lakukan proses yang sama pada bulan berikutnya (februari, maret, april, mei, juni, juli agustus) untuk mendapatkan nilai rata-rata bulan september dan bulan selanjutnya. Kemudian kita jumlahkan data nilai rata-rata tersebut, mulai dari awal pertama menghitung nilai rata-rata, dan mendapatkan hasil 53 data. Proses perhitungan selanjutnya yaitu mengukur tingkat akurasi pada setiap data, dengan memasukkan rumus MSE untuk menentukan nilai eror. Dari data $\mathrm{Ma}(7)$, hasil penjualan pada bulan agustus dikurang dengan hasil $\mathrm{Ma}(7)$ kemudian dikuadratkan, dan mendapat nilai eror 1976032,653. Lakukan proses yang sama pada setiap bulan berikutnya. Kemudian kita jumlahkan semua hasil nilai eror yang dikuadratkan sebelumnya. Dan mendapat nilai SSE 14009510, hasil tersebut dibagi dengan jumlah awal data yang dihitung. 14009510/53 dan mendapatkan nilai MSE 264330 .

Hasil perhitungan single moving average menggunakan $\mathrm{Ma}(7)$ dapat dilihat pada tabel 3.4.

Tabel 3.4 : Perhitungan Single Moving Average Menggunakan Ma(7)

\begin{tabular}{llllll}
\hline Tahun & Bulan & Penjulan (ds) & Penjulan $(\mathrm{pcs})$ & $\mathrm{Ma}(7)$ & $\mathrm{e}^{\wedge} 2$ \\
\hline \multirow{2}{*}{2013} & Januari & 110 & 1320 & & \\
& Februari & 100 & 1200 & &
\end{tabular}

Implementation of Single Moving Average Methods For Sales Forecasting Of Bag In Convection Tas Loram Kulon (Dewi) 


\begin{tabular}{|c|c|c|c|c|}
\hline Maret & 135 & 1620 & & \\
\hline April & 130 & 1560 & & \\
\hline Mei & 175 & 2100 & & \\
\hline Juni & 160 & 1920 & & \\
\hline Juli & 190 & 2280 & & \\
\hline Agustus & 260 & 3120 & 1714,286 & 1976032,653 \\
\hline September & 220 & 2640 & 1971,429 & 446987,7551 \\
\hline Oktober & 185 & 2220 & 2177,143 & 1836,734694 \\
\hline November & 200 & 2400 & 2262,857 & 18808,16327 \\
\hline Desember & 220 & 2640 & 2382,857 & 66122,44898 \\
\hline Januari & 285 & 3420 & 2460 & 921600 \\
\hline Februari & 280 & 3360 & 2674,286 & 470204,0816 \\
\hline Maret & 285 & 3420 & 2828,571 & 349787,7551 \\
\hline April & 255 & 3060 & 2871,429 & 35559,18367 \\
\hline Mei & 270 & 3240 & 2931,429 & 95216,32653 \\
\hline Juni & 235 & 2820 & 3077,143 & 66122,44898 \\
\hline Juli & 250 & 3000 & 3137,143 & 18808,16327 \\
\hline Agustus & 270 & 3240 & 3188,571 & 2644,897959 \\
\hline September & 285 & 3420 & 3162,857 & 66122,44898 \\
\hline Oktober & 280 & 3360 & 3171,429 & 35559,18367 \\
\hline November & 285 & 3420 & 3162,857 & 66122,44898 \\
\hline Desember & 270 & 3240 & 3214,286 & 661,2244898 \\
\hline Januari & 275 & 3300 & 3214,286 & 7346,938776 \\
\hline Februari & 295 & 3540 & 3282,857 & 66122,44898 \\
\hline Maret & 285 & 3420 & 3360 & 3600 \\
\hline April & 290 & 3480 & 3385,714 & 8889,795918 \\
\hline Mei & 300 & 3600 & 3394,286 & 42318,36735 \\
\hline Juni & 295 & 3540 & 3428,571 & 12416,32653 \\
\hline Juli & 295 & 3540 & 3445,714 & 8889,795918 \\
\hline Agustus & 285 & 3420 & 3488,571 & 4702,040816 \\
\hline September & 265 & 3180 & 3505,714 & 106089,7959 \\
\hline Oktober & 250 & 3000 & 3454,286 & 206375,5102 \\
\hline November & 235 & 2820 & 3394,286 & 329804,0816 \\
\hline Desember & 250 & 3000 & 3300 & 90000 \\
\hline Januari & 245 & 2940 & 3214,286 & 75232,65306 \\
\hline Februari & 220 & 2640 & 3128,571 & 238702,0408 \\
\hline Maret & 180 & 2160 & 3000 & 705600 \\
\hline April & 185 & 2220 & 2820 & 360000 \\
\hline Mei & 210 & 2520 & 2682,857 & 26522,44898 \\
\hline Juni & 245 & 2940 & 2614,286 & 106089,7959 \\
\hline Juli & 260 & 3120 & 2631,429 & 238702,0408 \\
\hline
\end{tabular}

TRANSFORMATIKA Vol.16, No.2, January 2019, pp. 113 - 125 


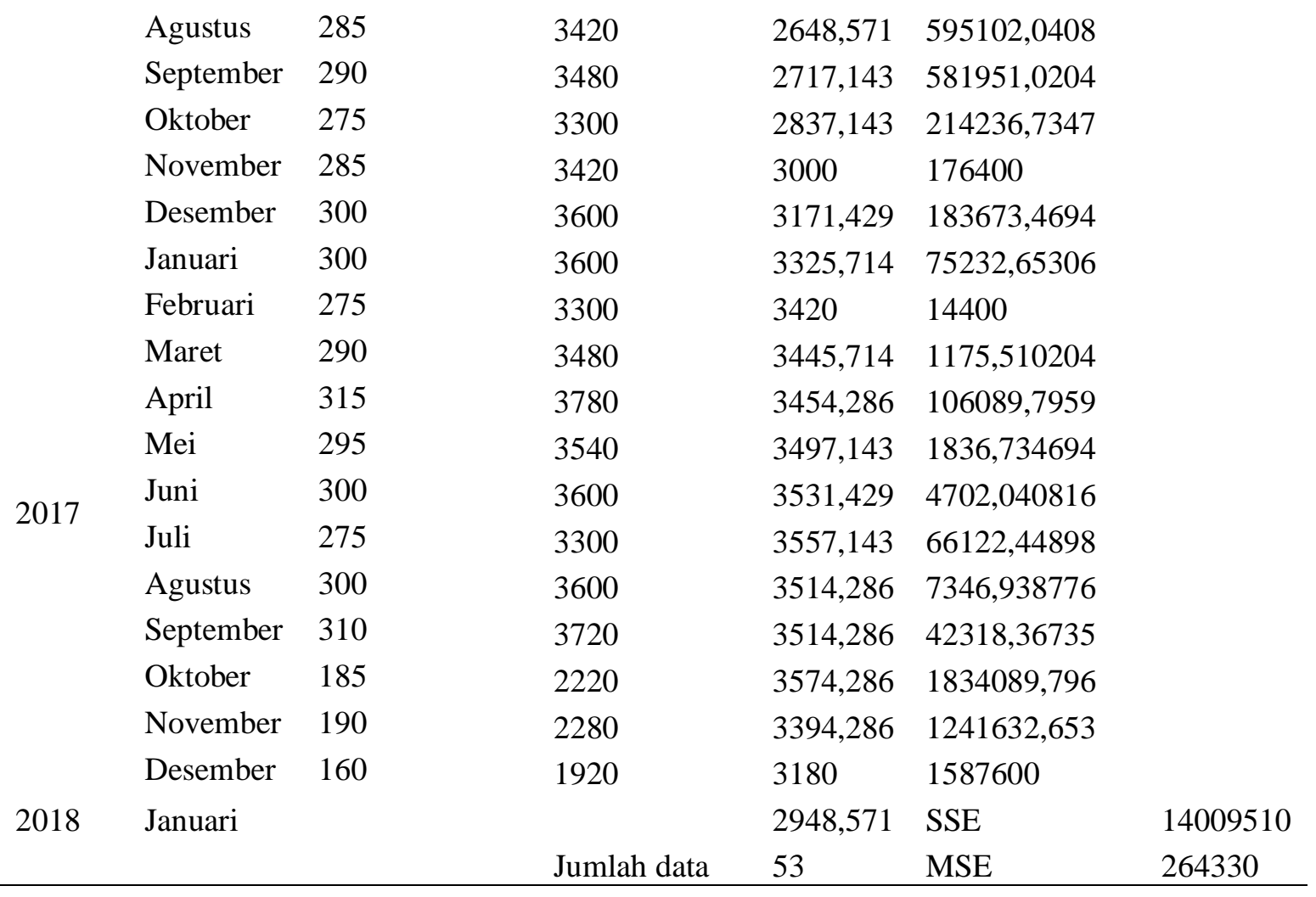

\subsection{Hasil dari perhitungan.}

Dari perhitungan data penjualan diatas, dari ke 3 orde metode single moving average diperoleh hasil peramalan penjualan yaitu menggunakan orde 3 (Ma3) sebesar 2140 pcs dengan rata-rata nilai eror sebesar 174779. Perhitungan menggunakan orde 5 (Ma5) diperoleh hasil peramalan penjualan sebesar 2748 pcs dengan rata-rata nilai eror sebesar 217657. Dan perhitungan menggunakan orde 7 (Ma7) diperoleh hasil peramalan penjualan sebesar 2948,571 pcs dengan rata-rata nilai eror sebesar 264330. Berikut hasil perhitungan yang digambarkan dalam sebuah grafik, dapat dilihat pada bagan 1 .

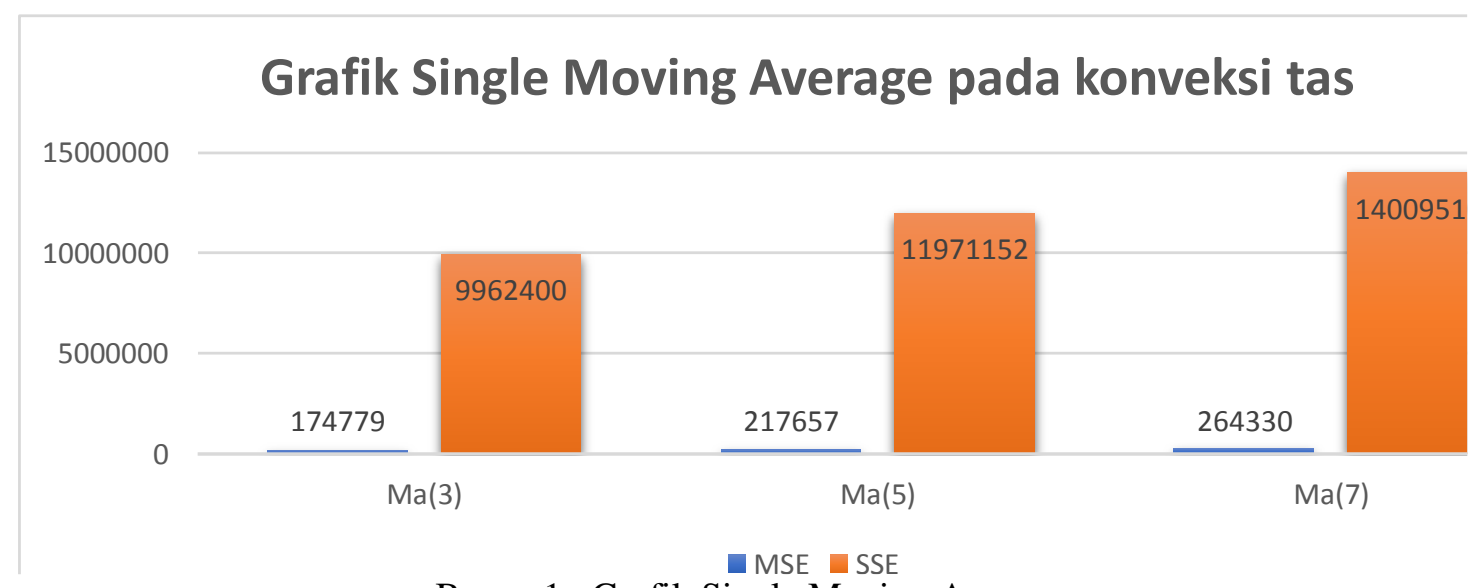

Bagan 1 : Grafik Single Moving Average.

Implementation of Single Moving Average Methods For Sales Forecasting Of Bag In Convection Tas Loram Kulon (Dewi) 


\section{Kesimpulan}

Berdasarkan penelitian yang telah dilakukan, untuk menentukan ramalan penjulan tas, pada konveksi tas loram kulon dari data penjualan sebelumnya, maka digunakan perhitungan dari metode single moving average untuk menentukan jumlah tas yang akan diproduksi bulan berikutnya.

Dari perhitungan menggunakan metode single moving average yang dilakukan, dapat disimpulkan bahwa peramalan menggunakan orde 3 (Ma3) menghasilkan nilai eror yang paling kecil dibanding dua orde lainnya. Dikarenakan dari hasil MSE dan SSE orde 3 (Ma3) menunjukkan nilai eror yang paling kecil dan menunjukan hasil produksi tas yang stabil. Dengan hasil yang didapat nilai MSE sebesar 174779 dan SSE sebesar 9962400 dan tas yang akan diproduksi sebanyak 2140 pcs.

Dalam membangun sistem diperlukan beberapa komponen utama, yaitu input data historis kemudian diproses dengan rumus dari metode single moving average serta menghasilkan output berupa penjualan hasil peramalan.

\section{References}

[1] M. B. Ismiati and L. Hermawan, "Penentuan Error Dalam Peramalan Jumlah Korban Demam Berdarah Dengue Menggunakan Metode Neural Network ( Kasus : Rumah Sakit Charitas Palembang )," J. Transform., vol. 14, pp. 23-29, 2016.

[2] W. Kurniadi, "Pendukung Keputusan Dalam Peramalan Penjualan Ayam Broiler Dengan Metode Trend Moment Dan Simple Moving Average Pada CV. Merdeka Adi Perkasa," MEDIA Inform. BUDIDARMA, vol. 2, pp. 76-90, 2018.

[3] A. A. Chamid and A. C. Murti, "Prioritization of Natural Dye Selection In Batik Tulis Using AHP and TOPSIS Approach," IJCCS (Indonesian J. Comput. Cybern. Syst., vol. 12, no. 2, p. 129, 2018.

[4] A. Abdul Chamid and B. Surarso, "Implementasi Metode AHP dan Promethee Untuk Pemilihan Supplier,” J. Sist. Inf. Bisnis, vol. 02, pp. 13-2015, 2015.

[5] Larose, Discovering Knowledge in Data Mining. New Jersey, 2005.

[6] najih izzan, "Implementasi Aloritma Sigle moving Average untuk Meramalkan Harga Kacang Hijau di Kabupaten Pati," J. Simetris, 2017.

[7] Assauri, Teknik dan Metoda Peramalan. Jakarta: Lembaga Penerbit Fakultas Ekonomi Universitas Indonesia, 1984.

[8] yulia ratih Hayuningtyas, "Peramalan Persediaan Barang Menggunakan Metode Weighted Moving Average dan Metode Double Exponential Smoothing," Pilar Nusa Mandiri, vol. 13, no. 2, pp. 217-222, 2017.

[9] E. Turban and J. Aronson, Decision Support Systems and Intelligent Systems. New Jersey: Prentice Hall Internasional, Inc, 2014. 